\title{
Applications of Artificial Intelligence in Marketing
}

\author{
Vinchhi DEVANG ${ }^{\star}$, Shroff CHINTAN ${ }^{\star \star}$, Tanna GUNJAN ${ }^{\star \star \star}$, Rai KRUPA $^{\star \star \star \star}$
}

\begin{tabular}{l}
\hline \multicolumn{1}{c}{ A R T I C L E I N F O } \\
\hline Article history: \\
Accepted February 2019 \\
Available online April 2019 \\
\hline JEL Classification \\
M31, L86 \\
Keywords: \\
Adoption of AI by organizations, AI \\
applications in marketing, Artificial \\
intelligence, Use of AI applications
\end{tabular}

\begin{abstract}
A B S T R A C T
Artificial intelligence is the simulation of human intelligence processes by machines, which covers a huge range of capabilities such as voice/image recognition, decision making, machine learning techniques and semantic search. Through secondary research, this paper aims at educating marketers on the present and future potential of artificial intelligence by providing some real-world examples of few early-adopting firms and connecting them with AI powered technologies that can improve marketing performance and transform their businesses. Through primary research, this paper aims at studying the impact of artificial intelligence on the overall marketing landscape. In the end the paper makes a modest attempt to identify those sectors which have shown good acceptability for AI in marketing and the ones which will benefit the most.
\end{abstract}

(C) 2019 EAI. All rights reserved.

\section{Introduction}

Artificial intelligence can be defined as the simulation of human intelligence processes by machines, which ranges across capabilities such as voice/image recognition, decision making, semantic search and machine learning techniques. Artificial intelligence is the next big thing and is expected to create a wave of disruption in digital technologies.

USA and China dominate the entire AI landscape with investments of $\$ 5-8 \mathrm{Bn}$ and $\$ 1.5-2.5 \mathrm{Bn}$ respectively in 2016 followed by Europe with investments of $\$ 1.1-1.7 \mathrm{Bn}$. Although the investment in AI is growing at the rate of approximately three folds since 2013, overall the adoption of AI remains quite low at only $20 \%$ of the entire market (McKinsey, 2017). "In one of the studies published by IBM Institute for Business Value, companies which outperformed their peers in various financial measures are more likely to believe they are ready to adopt cognitive computing (88\%) than other companies (57\%). They are also more likely to believe that the technology will be important to their organization's future (91\% vs $64 \%$ ) and that AI is mature enough to be market ready (93\% vs 59\%)" (John Ellett, 2017).

AI deployment will accelerate at the digital frontier which will in turn lead to expansion in the gap between adopters and laggards across various sectors, industries and geographies. AI is finding its application across the value chain; however major investments are directed towards the parts of value chain which are to the core of the company. Peter Drucker once said business enterprise has two--and only two-basic functions: marketing and innovation. Hence, sales and marketing which generates huge amount of data, has been one of the critical component of value chain which has got a lot of acceptance of AI (McKinsey, 2017).

AI applications though being used across the value chain around the world, the benefits so provided by them are yet to be analyzed from an Indian perspective. We are yet to understand how organizations in India are adopting AI in their daily businesses and whether Indian customers are ready to accept AI.

\section{Literature review}

Artificial Intelligence defines technologies rising these days which will perceive, learn, so act supported that information varieties of AI in use these days embrace digital assistants, chatbots, and machine learning. Today, AI works in 3 ways, a) aided intelligence, wide offered these days, improves what individuals and organizations are already doing. An easy example, rife in cars these days, is that the GPS navigation program that gives directions to drivers and adjusts to road conditions, b) increased intelligence, rising these days, allows individuals and organizations to try to to things they couldn't otherwise do. For example, the mixture of programs that organize cars in ride-sharing services permits businesses that might not otherwise exist. c) Autonomous intelligence, being developed for the longer term, establishes machines that act on their own. Associate example of this may be self-driving vehicles, once they acquire widespread use. 
With a market projected to succeed in $\$ 70$ billion by 2020 , AI is poised to own a transformative impact on shopper, enterprise, and government markets round the world. Whereas there are actually obstacles to beat, shoppers believe that AI has the potential to help in medical breakthroughs, democratize pricey services, elevate poor client service, associated even unlock a burdened force. Some school optimists believe AI might produce a world wherever human skills are amplified as machines facilitate human race method, analyze, and judge the abundance of knowledge that makes today's world, permitting humans to pay longer engaged in high-level thinking, creativity, and decision-making.

As a future with AI approaches, it's vital to know however individuals consider it nowadays, however it'll amplify the globe tomorrow, and what guiding principles are going to be needed to navigate this monumental modification (PwC, 2017).

The applications mentioned below with respective real-world examples help us understand how few early-adopting firms significantly improved customer satisfaction and customer retention; thereby increasing their revenue. Thus, we can say that implementation of AI applications leads to significant improvement in marketing performance and profitability. However, rate of adoption of AI in India is slow when compared to other countries apart from few sectors like BFSI. BFSI as a sector has seen accelerated adoption of AI in the last couple of years and is predicted to do so in the future (Accenture, 2017). Banks in India like ICICI have been able to reduce their turnaround time for processes such as disputed transactions by $80 \%$ with the help of AI (LiveMint, 2017). Most of the AI technologies implemented by firms in BFSI sector can also be used by firms in other sectors like Retail, Telecom, Media/Entertainment etc. to not only improve their marketing performance but also transform their businesses.

Table 1. List of AI applications

\begin{tabular}{|c|c|c|c|}
\hline $\begin{array}{l}\text { Name of the } \\
\text { Application }\end{array}$ & Feature & Case Example & Benefits Obtained \\
\hline Saffron & $\begin{array}{c}\text { Predictive } \\
\text { customer service }\end{array}$ & $\begin{array}{l}\text { USAA tested it to enhance customer service by } \\
\text { effectively foreseeing how a certain customer } \\
\text { may next get in touch with USAA }\end{array}$ & $\begin{array}{l}\text { Effectiveness of their } \\
\text { prediction increased from } \\
50 \% \text { to } 88 \%\end{array}$ \\
\hline Albert & $\begin{array}{l}\text { Marketing } \\
\text { automation }\end{array}$ & $\begin{array}{l}\text { Harley Davidson made use of Albert to } \\
\text { centralize and automate their online marketing } \\
\text { campaigns right from optimization to execution }\end{array}$ & $\begin{array}{l}\text { Dealership leads increased } \\
\text { by } 29 \text { times within three } \\
\text { months }\end{array}$ \\
\hline Persado & $\begin{array}{l}\text { 1:1 Dynamic e- } \\
\text { mails }\end{array}$ & $\begin{array}{l}\text { Citi used this cognitive content platform which } \\
\text { combines Machine learning and NLP to } \\
\text { generate exact words and phrases which can } \\
\text { inspire an individual to act }\end{array}$ & $\begin{array}{l}\text { Citi's e-mail open rate } \\
\text { increased by } 70 \% \text { and click } \\
\text { to open rate by } 114 \%\end{array}$ \\
\hline Conversica & $\begin{array}{l}\text { Lead scoring - } \\
\text { Automated sales } \\
\text { assistant software }\end{array}$ & $\begin{array}{l}\text { CenturyLink, a telecom company, used this } \\
\text { application which reaches, engages, qualifies } \\
\text { and follows-up with leads in a two-way email } \\
\text { exchange }\end{array}$ & $\begin{array}{l}\text { CenturyLink's ROI came up } \\
\text { to } \$ 20 \text { for every dollar } \\
\text { invested }\end{array}$ \\
\hline Layer 6 AI & Predictive analytics & $\begin{array}{l}\text { Deep learning platform for prediction and } \\
\text { personalization of suggestions using } \\
\text { transaction history, customer profile, etc. }\end{array}$ & $\begin{array}{l}\text { Netflix's AI } \\
\text { recommendation platform } \\
\text { helps them save } \$ 1 \text { bn } \\
\text { making a significant ROI }\end{array}$ \\
\hline Wordsmith & Content generation & $\begin{array}{l}\text { Yahoo uses Wordsmith which is a NLG platform } \\
\text { to help convert their data from fantasy football } \\
\text { into detailed match previews, recaps and } \\
\text { reports }\end{array}$ & $\begin{array}{l}\text { Yahoo has added over } 100 \\
\text { years equivalent of } \\
\text { incremental audience } \\
\text { engagement by working } \\
\text { with Wordsmith }\end{array}$ \\
\hline IBM Watson & Content curation & $\begin{array}{l}\text { Wimbledon used Watson which is a cognitive } \\
\text { system enabling new partnership between } \\
\text { people and computers }\end{array}$ & $\begin{array}{l}\text { Watson helped Wimbledon } \\
\text { maintain its digital } \\
\text { viewership and increase } \\
\text { video views by } 25 \% \text { even } \\
\text { after having international } \\
\text { sports activities going on in } \\
\text { parallel }\end{array}$ \\
\hline Centiment & Social semantics & $\begin{array}{l}\text { Euler Hermes used Centiment to gain insights of } \\
\text { their customers' feelings about their brand and } \\
\text { product }\end{array}$ & $\begin{array}{l}\text { Euler Hermes' inbound } \\
\text { leads increased by } 38.1 \% \\
\text { with projected conversion } \\
\text { of } 51.98 \%\end{array}$ \\
\hline
\end{tabular}

\subsection{Research Question/Problem Statement}

To understand how is AI disrupting marketing landscape?

To understand if organizations should adopt these AI powered applications for their marketing and sales or is it just a fad? 


\section{2. $\quad$ Research Objective}

The aim of this study is to understand the role AI powered applications played in increasing the sales of an Indian organization by improving the effectiveness of marketing and sales plan. Towards this, research objective has been divided into three parts:

i. $\quad$ To study how AI applications help improve 1:1 marketing and move away from mass marketing

ii. To study how AI enhances consumer convenience leading to increasing sales and market share for an organization

iii. To identify the current adoption of AI applications by organizations in different sectors

\subsection{Research Gap and Research Problem}

AI applications are being used across the value chain in all organizations of various sectors from different continents. However, what benefits these organizations have received has to be studied from an Indian perspective. Should the other organizations be a naysayer and ignore this changing trend or adopt and be a leader is yet unknown. A comprehensive study needs to be done to know which applications of AI have been adopted and what effect does it have in transforming the marketing landscape.

\subsection{Research methodology}

To understand the impact of AI on overall marketing landscape in India, we will be using mixed method research wherein we will be performing qualitative research (interview and observation) to understand the perception of organizations towards adoption of $\mathrm{AI}$ in India and implications of the adopting $\mathrm{AI}$; and quantitative research (surveys) for understanding consumer's acceptability of AI.

\section{Qualitative Analysis}

Table 2 For the qualitative analysis, data was collected from organizations pertaining to different sectors

\begin{tabular}{|c|c|c|}
\hline Designation & Domain & Key Comments \\
\hline $\begin{array}{l}\text { Head } \\
\text { Emerging } \\
\text { Markets }\end{array}$ & Travel Industry & $\begin{array}{l}\text { Low acceptance of digitization in India hampers AI's growth in India } \\
\text { AI is currently more beneficial in customer retention rather than } \\
\text { customer acquisition } \\
\text { BFSI and e-commerce will benefit the most due to abundance of } \\
\text { existing data } \\
\text { "Smart AI, helps search Smart Customer, thus get Smarter Data, thus } \\
\text { make AI smarter" }\end{array}$ \\
\hline CEO & $\begin{array}{c}\text { Chatbot Platform - } \\
\text { HR Domain }\end{array}$ & $\begin{array}{l}\text { Future of AI in India seems quite patchy and innovation in gathering } \\
\text { datasets should be concentrated on } \\
\text { BFSI and Telecom will be the first to adopt AI because of being under } \\
\text { constant profitability pressure } \\
\text { Telecom is actively tracking our social media data to enhance their } \\
\text { sales by effectively targeting customers for acquisition }\end{array}$ \\
\hline $\begin{array}{c}\text { Digital } \\
\text { Transformati } \\
\text { on Lead }\end{array}$ & $\begin{array}{l}\text { Pharmaceutical } \\
\text { Industry }\end{array}$ & $\begin{array}{l}\text { Companies in India don't fully understand what AI is, how it works or } \\
\text { how to leverage its full potential } \\
\text { Some of the reasons for low adoption of AI in India include: } \\
\text { Data from various departments is siloed } \\
\text { Data is not frequently collected and speed of acting on it is not as fast } \\
\text { as it should be } \\
\text { Data collected may not be analyzed for the right insight } \\
\text { Machine learning as a concept has not evolved and companies in India } \\
\text { don't know what to make out of the huge amount of data collected }\end{array}$ \\
\hline $\begin{array}{l}\text { Co-Founder } \\
\text { and CEO }\end{array}$ & $\begin{array}{l}\text { Chatbot Platform - } \\
\text { Marketing \& Sales } \\
\text { Domain }\end{array}$ & $\begin{array}{l}\text { Most of the large organizations are adopting } \mathrm{AI} \text { in India in a race } \\
\text { towards innovation } \\
\text { Organizations are not aware of AI's potential and are therefore } \\
\text { adopting it to test its performance } \\
\text { Most of the Indian banks have adopted chatbots, not strategically but } \\
\text { to test its performance } \\
\text { BFSI and Automotive sector are the frontrunners in the adoption of AI }\end{array}$ \\
\hline
\end{tabular}

\subsection{Quantitative Analysis}

The questionnaire was designed in accordance with the research objectives to understand Indian consumer's acceptability of AI based on the following parameters of reference:

i. Willingness to use $\mathrm{AI}$ in personalization of services 
ii. Ease of use of AI

iii. Actual adoption of AI

Personalization of services refers to the customization of services based upon consumer preference while adoption of AI refers to the consumers' acceptance of AI.

\subsection{Demographics}

The survey was conducted amongst the millennials (age group of 22-37). Millennials were chosen for the survey since they are early adopters of latest technologies and are the future beneficiaries of the same. There were 302 responses which were obtained out of which 26 were outliers and hence 276 responses were analyzed. Convenience sampling was used.

\subsection{Data Analysis}

The data collected was analyzed using SPSS as a tool. The preliminary part of the questionnaire recorded the information on Age, Gender, Income and the frequency of internet usage while the other questions aimed at recording their level of agreement or disagreement towards adoption of AI in customer support services, online shopping websites and virtual assistants.

\section{Results and Discussion}

\subsection{Personalization and 1:1 Marketing}

AI helps in providing a more personalized service experience by understanding the consumer preference and tailoring the service based on the same. From the research point of view before understanding how much impact adoption of AI in personalization of services would have from an Indian perspective, it is imperative to understand Indian consumers' willingness towards personalization of services.

\section{Hypothesis:}

$\mathbf{H}_{\mathbf{0 A}}$ : There is no willingness towards adoption of $\mathrm{AI}$ in personalization of services

$\mathbf{H}_{\mathbf{1 A}}$ : There is willingness towards adoption of $\mathrm{AI}$ in personalization of services

Indian consumers' preference towards personalization of experience with respect to e-commerce websites was used while framing the research questionnaire. This was due to the high degree of familiarity of the target audience with the same.

Table 3 a Preference for personalization* Purchase from recommendations on e-commerce websites Crosstabulation

\begin{tabular}{|c|c|c|c|c|}
\hline \\
\hline & & \multicolumn{2}{|c|}{$\begin{array}{l}\text { Purchase from } \\
\text { recommendations on e- } \\
\text { commerce websites }\end{array}$} & \multirow[t]{2}{*}{ Total } \\
\hline & & Yes & No & \\
\hline \multirow{6}{*}{ Preference for personalization } & Count & 24 & 66 & 90 \\
\hline & $\begin{array}{l}\% \text { within Preference for } \\
\text { personalization }\end{array}$ & $26.7 \%$ & $73.3 \%$ & $100.0 \%$ \\
\hline & $\%$ of Total & $8.7 \%$ & $23.9 \%$ & $32.6 \%$ \\
\hline & Count & 36 & 42 & 78 \\
\hline & $\begin{array}{l}\text { \% within Preference for } \\
\text { personalization }\end{array}$ & $46.2 \%$ & $53.8 \%$ & $100.0 \%$ \\
\hline & $\%$ of Total & $13.0 \%$ & $15.2 \%$ & $28.3 \%$ \\
\hline
\end{tabular}

Table 3 b Chi-Square Tests

\begin{tabular}{cccc}
\hline & Value & df & $\begin{array}{c}\text { Asymp. Sig. (2- } \\
\text { sided) }\end{array}$ \\
\hline Pearson Chi-Square & $7.720^{\mathrm{a}}$ & 2 & .021 \\
\hline
\end{tabular}

Table 3c Symmetric Measures

\begin{tabular}{|c|c|c|c|c|}
\hline & & Value & $\begin{array}{l}\text { Asymp. Std. Approx. T } \\
\text { Error }^{\mathrm{b}}\end{array}$ & Approx. Sig. \\
\hline \multirow{3}{*}{ Nominal by Nominal } & Phi & .167 & & .021 \\
\hline & Cramer's V & .167 & & .021 \\
\hline & Contingency Coefficient & .165 & & .021 \\
\hline
\end{tabular}


From the above table it can be observed that maximum number of respondents who are currently not purchasing from the recommendations provided on the e-commerce websites, feel that the recommendations provided are too generic and should be more personalized.

Table 4 a Usefulness of recommendations provided on e-commerce websites * Purchase attitude towards websites with virtual trial Crosstabulation

Purchase attitude towards websites with virtual trial Most Likely Likely Neutral

\begin{tabular}{llll} 
Count & 18 & 36 & 15 \\
\hline
\end{tabular}

Useful \% within Usefulness of recommendations provided on e-commerce websites

\begin{tabular}{lrrr}
${ } }$ & $6.5 \%$ & $13.0 \%$ & $5.4 \%$ \\
\hline Count & 36 & 51 & 24 \\
\hline
\end{tabular}

Usefulness of recommendations provided on e-

Neutral \% within Usefulness of recommendations commerce websites provided on e-commerce websites

\begin{tabular}{lrrr}
\hline \% of Total & $13.0 \%$ & $18.5 \%$ & $8.7 \%$ \\
\hline Count & 6 & 9 & 15 \\
\hline
\end{tabular}

Not $\%$ within Usefulness of recommendations

Useful provided on e-commerce websites

Table 4 b Chi-Square Tests

\begin{tabular}{lcrr}
\hline & Value & df & \multicolumn{2}{c}{$\begin{array}{c}\text { Asymp. Sig. (2- } \\
\text { sided) }\end{array}$} \\
\hline Pearson Chi-Square & $65.927^{\mathrm{a}}$ & 16 & .000 \\
\hline
\end{tabular}

Table 4 c Symmetric Measures

\begin{tabular}{|c|c|c|c|c|}
\hline & & Value & $\begin{array}{l}\text { Asymp. Std. } \\
\text { Error }^{\mathrm{a}}\end{array}$ & Approx. Sig. \\
\hline \multirow{3}{*}{ Nominal by Nominal } & Phi & .489 & & .000 \\
\hline & Cramer's V & .244 & & .000 \\
\hline & Contingency Coefficient & .439 & & .000 \\
\hline
\end{tabular}

From the above table it can be observed that the respondents who are neutral about the usefulness of the recommendations provided on the e-commerce websites, have shown a higher preference towards buying online if there is an option of virtual trial provided.

\section{Hypothesis Test Result}

Assuming the confidence level of $95 \%$, it can be observed that in both the cases (referring to the significance value of PHI and Cramer's V) the significance value is less than 0.05 . Therefore, null hypothesis is rejected. Thus, it can be concluded that there is willingness towards adoption of AI in personalization of services.

\subsection{Customer service}

AI can not only help reduce cost at the organizations end but also enhance customer convenience by automating customer support service. From the research point of view before understanding how much impact adoption of AI in Customer Support Service applications would have from an Indian perspective, it is imperative to understand Indian consumers' comfortability with using automated customer support service and their preference towards using the same. 


\section{Hypothesis:}

$\mathbf{H}_{\mathbf{0 B}}$ : There is no willingness towards adoption of AI in Customer Support Service applications

$\mathbf{H}_{1 \mathrm{~B}}$ : There is willingness towards adoption of AI in Customer Support Service applications

Indian consumers' preference towards mode of communication with the customer support and perceived ease of use of each mode of communication was used while framing the research questionnaire due to the nature of current AI powered customer support service applications (mostly uses texting as a mode of communication).

Table 5 a Preference for communication * Ease of use for texting over call Crosstabulation

\begin{tabular}{|c|c|c|c|c|c|c|}
\hline & & & \multicolumn{4}{|c|}{ Ease of use for texting over call } \\
\hline & & & Very Easy & Easy & Neutral & Cumbersome \\
\hline \multirow{6}{*}{ Preference for communication } & \multirow{3}{*}{ Phone } & Count & 15 & 54 & 93 & 30 \\
\hline & & $\begin{array}{l}\text { \% within Preference for } \\
\text { communication }\end{array}$ & $7.5 \%$ & $26.9 \%$ & $46.3 \%$ & $14.9 \%$ \\
\hline & & $\%$ of Total & $5.4 \%$ & $19.6 \%$ & $33.7 \%$ & $10.9 \%$ \\
\hline & \multirow{3}{*}{ Text } & Count & 18 & 18 & 21 & 12 \\
\hline & & $\begin{array}{l}\text { \% within Preference for } \\
\text { communication }\end{array}$ & $24.0 \%$ & $24.0 \%$ & $28.0 \%$ & $16.0 \%$ \\
\hline & & $\%$ of Total & $6.5 \%$ & $6.5 \%$ & $7.6 \%$ & $4.3 \%$ \\
\hline
\end{tabular}

Table 5 b Chi-Square Tests

\begin{tabular}{lcrr}
\hline & Value & $\mathrm{df}$ & \multicolumn{2}{c}{$\begin{array}{c}\text { Asymp. Sig. (2- } \\
\text { sided) }\end{array}$} \\
\hline Pearson Chi-Square & $18.367^{a}$ & 4 & .001 \\
\hline
\end{tabular}

Table 5 c Symmetric Measures

\begin{tabular}{|c|c|c|c|c|}
\hline & & Value & $\begin{array}{l}\text { Asymp. Std. Approx. T } \\
\text { Error }^{\mathrm{b}}\end{array}$ & Approx. Sig. \\
\hline \multirow{3}{*}{ Nominal by Nominal } & Phi & .258 & & .001 \\
\hline & Cramer's V & .258 & & .001 \\
\hline & Contingency Coefficient & .250 & & .001 \\
\hline
\end{tabular}

From the above table it can be observed that even though people find texting easier than calling, their preference for using phone is still higher than texting. This can be attributed to the fact that there is higher emotional connect established through calling due to the presence of a human factor. AI can help integrate the human factor with texting, making it preferred mode of communication.

\section{Hypothesis Test Result:}

Assuming the confidence level of $95 \%$, it can be observed that the Cramer's V significance value comes out to be 0.001 which is less than 0.05 . Therefore, null hypothesis is rejected. Thus, there is willingness towards adoption of AI in customer support service applications.

\subsection{Virtual Assistants}

AI can create a huge impact on how daily chores are carried out by helping automate various day to day applications. From the research point of view before understanding how much impact adoption of AI in day to day applications would have from an Indian perspective, it is imperative to understand Indian consumers' preference towards using AI in day to day applications.

\section{Hypothesis:}

$\mathbf{H}_{\mathbf{0 c}}$ : There is no willingness towards adoption of AI in day to day applications

$\mathbf{H}_{1 \mathrm{c}}$ : There is willingness towards adoption of $\mathrm{AI}$ in day to day applications

Indian consumers' preference towards use of mobile/virtual assistants in day to day applications and the perceived ease of use of the mobile/virtual assistants was used while framing the research questionnaire due to the high degree of familiarity of the target audience with the same. 
Table 6 a Frequency of use for mobile assistants * Ease of use for mobile assistants Crosstabulation

Ease of use for mobile assistants

\begin{tabular}{|c|c|c|c|c|c|c|}
\hline & & & \\
\hline & & & Very Easy & Easy & Neutral & Cumbersome \\
\hline \multirow{9}{*}{$\begin{array}{l}\text { Frequency of use for } \\
\text { mobile assistants }\end{array}$} & \multirow{3}{*}{ Neutral } & Count & 12 & 24 & 36 & 0 \\
\hline & & $\begin{array}{l}\% \text { within Frequency of } \\
\text { use for mobile assistants }\end{array}$ & $16.7 \%$ & $33.3 \%$ & $50.0 \%$ & $0.0 \%$ \\
\hline & & $\%$ of Total & $4.3 \%$ & $8.7 \%$ & $13.0 \%$ & $0.0 \%$ \\
\hline & \multirow{3}{*}{ Sometimes } & Count & 3 & 27 & 36 & 24 \\
\hline & & $\begin{array}{l}\% \text { within Frequency of } \\
\text { use for mobile assistants }\end{array}$ & $3.3 \%$ & $30.0 \%$ & $40.0 \%$ & $26.7 \%$ \\
\hline & & $\%$ of Total & $1.1 \%$ & $9.8 \%$ & $13.0 \%$ & $8.7 \%$ \\
\hline & \multirow{3}{*}{ Never } & Count & 0 & 15 & 36 & 15 \\
\hline & & $\begin{array}{l}\% \text { within Frequency of } \\
\text { use for mobile assistants }\end{array}$ & $0.0 \%$ & $19.2 \%$ & $46.2 \%$ & $19.2 \%$ \\
\hline & & $\%$ of Total & $0.0 \%$ & $5.4 \%$ & $13.0 \%$ & $5.4 \%$ \\
\hline
\end{tabular}

Table 6 b Chi-Square Tests

\begin{tabular}{lcrr}
\hline & Value & $\mathrm{df}$ & \multicolumn{2}{c}{$\begin{array}{c}\text { Asymp. Sig. (2- } \\
\text { sided) }\end{array}$} \\
\hline Pearson Chi-Square & $143.346^{a}$ & 16 & .000 \\
\hline
\end{tabular}

Table 6 c Symmetric Measures

\begin{tabular}{|c|c|c|c|c|}
\hline & & Value & $\begin{array}{l}\text { Asymp. Std. Approx. T } \\
\text { Error }^{\mathrm{b}}\end{array}$ & Approx. Sig. \\
\hline \multirow{3}{*}{ Nominal by Nominal } & Phi & .721 & & .000 \\
\hline & Cramer's V & .360 & & .000 \\
\hline & Contingency Coefficient & .585 & & .000 \\
\hline
\end{tabular}

From the above table it can be observed that even though the respondents were neutral about the ease of use for the virtual assistants, the frequency of usage for these types of assistants is quite low.

Table 7 a Ease of use for mobile assistants * Preference for usage of virtual assistants Crosstabulation

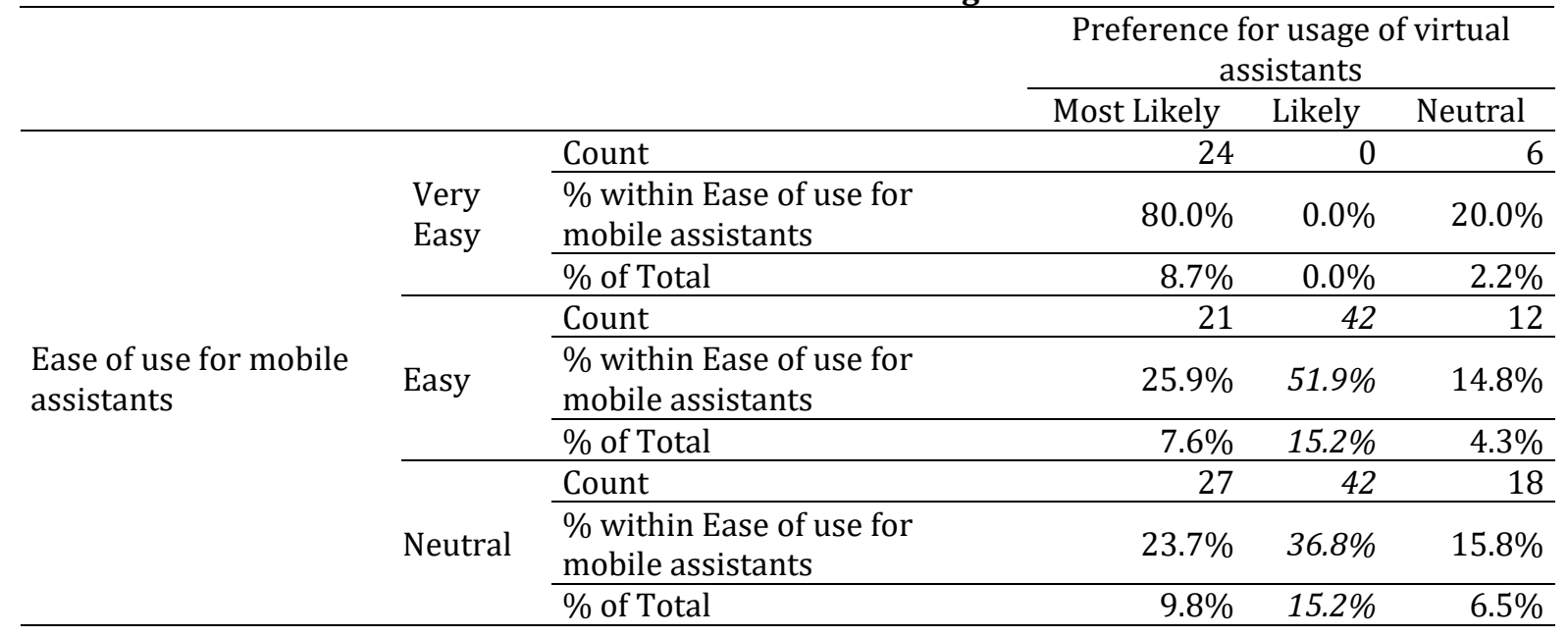

Table 7 b Chi-Square Tests

\begin{tabular}{lcrr}
\hline & Value & $\mathrm{df}$ & \multicolumn{2}{c}{$\begin{array}{c}\text { Asymp. Sig. (2- } \\
\text { sided) }\end{array}$} \\
\hline Pearson Chi-Square & $157.652^{a}$ & 16 & .000 \\
\hline
\end{tabular}


Table 7 c Symmetric Measures

\begin{tabular}{|c|c|c|c|c|c|}
\hline & & Value & $\begin{array}{c}\text { Asymp. Std. } \\
\text { Error }^{\mathrm{a}}\end{array}$ & Approx. $\mathrm{T}^{\mathrm{b}}$ & Approx. Sig. \\
\hline \multirow{3}{*}{ Nominal by Nominal } & Phi & .756 & & & .000 \\
\hline & Cramer's V & .378 & & & .000 \\
\hline & Contingency Coefficient & .603 & & & .000 \\
\hline
\end{tabular}

From the above table, it can be observed that the respondents who found virtual assistants easy or were neutral about the easiness of use, were more likely to adopt these types of assistants for practical repetitive tasks which can be automated.

\section{Hypothesis Test Result:}

Assuming the confidence level as $95 \%$, it can be observed that in both the above cases the Cramer's V significance value comes out to be less than 0.05 . Therefore, null hypothesis is rejected. Thus, there is willingness towards adoption of $\mathrm{AI}$ in day to day applications.

\section{Managerial Implications}

This section describes how AI can assist marketers and which applications of AI can be used for what purpose. As we infer from the quantitative inference that there is a gap between willingness and actual adoption of AI. In order to bridge this gap AI helps to move away from mass marketing and get towards 1:1 marketing.

AI can help marketers segment targets more accurately. Knowing segments accurately will help them make content more personalized for each individual. From the survey conducted by Forrester, 57\% would shop more if a feature of personalization were made available which is supported with $73 \%$, which we obtained from our primary research. This was from customers' point of view, coming towards business executives, $61 \%$ of them feel that AI can offer a superior one-to-one personalized experience. Example: AI application Persado writes dynamic emails.

Another way of filling this gap is by taking action in real time AI delivered insights. Example: IBM Watson, Albert helps in everyday planning, executing and reporting on campaigns. It helps in everything from optimization to execution.

\section{Consumer Convenience}

In order to address the issue of enhancing the consumer convenience, AI plays a critical role. AI can help in building emotional connect, though it is just a machine. For example, Centiment is a social semantics tool which helps marketers gain insight into the emotions of the customers thereby helping them understand how customers feel about their brand and product. It uses NLP, which is a component of AI to do so.

\section{Content Generation}

(NLG) is an AI application, which can generate stories on its own using existing sources of information like scores \& names of players of Fantasy football club. This brings convenience to user as they see stories on topics they love that too with little efforts from marketer's end, thereby proving superior consumer convenience. Thus, as marketers it becomes necessary to make maximum use of data to bring personalization and enhanced consumer experience.

\section{Lead nurturing}

Conversica (Automated Sales Assisting Software) is an AI driven software that automatically reaches, engages, qualifies and follows up with leads via a two-way email exchange.

\section{Data Governance}

With the increase in the data which is collected, AI can facilitate in generating bigger insights of the massive information by serving to perceive deeper levels of shopper insights and the way to effectively build shoppers have interaction. Advanced systems and advanced analytics can amendment the approach we tend to expertise data via our mobiles, our wearable and therefore the net of Things (IoT).

\section{Sectors Identified}

BFSI and Telecom will be the first to adopt AI, or as a matter of fact any kind of innovation since they are constantly under profitability pressure.

\section{Conclusion}

While there are several challenges to overcome, AI possesses the potential to solve many of today's problems and push Martech even further. This change can only be brought about if individuals and businesses co-create a man-machine hybrid which entails to be more powerful than either entity acting alone.

The government of India has taken proactive action towards digitization and is driving the AI agenda as well - from setting up a policy group for AI by the MEIT, to the Karnataka government's recent 
announcement of a data science and AI Centre of Excellence. NITI Aayog will be establishing a national program in the area of AI which will include research and development of its applications.

Altogether, these developments will eventually propel the evolution of an AI ecosystem and its applications in our day to day lives. Soon we will be witnessing 'augmented age'. To remain competitive in the current industrial scenario, it is necessary for the companies to adopt AI.

\section{References}

1. Accenture, 2017. [Online], Available at: https://www.accenture.com/us-en/perspectives-banking-tech-vision-2017mcintyre-westland

2. Automated Insights, 2017. Natural Language Generation / Yahoo! - Automated Insights, Inc.. [Online], Available at: https://automatedinsights.com/case-studies/yahoo

3. Centiment, 2017. Centiment \& Euler Hermes: Risk \& Social Application Case Study. [Online], Available at: https://centiment.io/beta/blog/wp-content/uploads/2017/06/EulerHermesCaseStudy.pdf

4. IBM, 2016. Wimbledon 2016. [Online], Available at: http://ecc.ibm.com/case-study/us-en/ECCF-WWC12371USEN

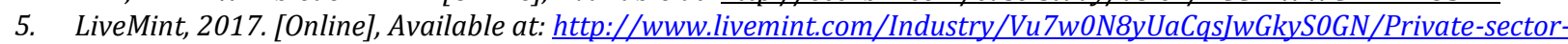
banks-looking-to-leverage-robotics-AI.html

6. McKinsey, 2017. Artficial Intelligence the Next Digital Frontier?, s.l.: McKinsey \& Company.

7. Anon, (2017). [online], Available at: http://www.martechadvisor.com/articles/customer-experience/recommendationengines-how-amazon-and-netflix-are-winning-the-personalization-battle, [Accessed 3 Nov. 2017].

8. Forbes.com. (2017). Forbes Welcome. [online] Available at: http://www.forbes.com/sites/johnellett/2017/09/13/ibmstudy-finds-outperforming-companies-more-ready-to-adopt-ai-for-marketing/\#b2a9c3a5952e, [Accessed 3 Nov. 2017].

9. AI software for marketing \& sales / Conversica / Convert more leads into opportunities. (2017). Customer Success Story: How CenturyLink gets $\$ 20$ return for every \$1 spent with Conversica. [online], Available at: http://www.conversica.com/customer-success-story-how-centurylink-gets-20-return-for-every-1-spent-withconversica/ [Accessed 3 Nov. 2017]

10. Haworth, E. (2017). Meet Albert, the AI that's better at your marketing job than you. [online] Cityam.com, Available at: http://www.cityam.com/268916/meet-albert-ai-thats-better-your-marketing-job-than-you [Accessed 3 Nov. 2017].

11. Harvard Business Review. (2017). How Harley-Davidson Used Artificial Intelligence to Increase New York Sales Leads by 2,930\%. [online], Available at: http://hbr.org/2017/05/how-harley-davidson-used-predictive-analytics-to-increasenew-york-sales-leads-by-2930 [Accessed 3 Nov. 2017].

12. TechRepublic. (2017). Persado uses artificial intelligence to help digital marketers write better copy. [online], Available at: https://www.techrepublic.com/article/persado-uses-artificial-intelligence-to-help-digital-marketers-write-bettercopy/ [Accessed 3 Nov. 2017].

13. imFORZA. (2017). Online Marketing with Artificial Intelligence / imFORZA. [online] Available at: https://www.imforza.com/blog/online-marketing-with-artificial-intelligence/[Accessed 3 Nov. 2017]

14. PWC, 2017. Bot.Me: A revolutionary partnership. [online], Available at: https://www.pwc.com/consumerintelligenceseries, [Accessed 3 Nov. 2017]. 